\title{
Neodrassex, a new genus of the Leptodrassex group (Araneae, Gnaphosidae) from South America
}

\author{
Ricardo Ott
}

Museu de Ciências Naturais, Fundação Zoobotânica do Rio Grande do Sul. Rua Dr. Salvador França, 1427, 90690-000 Porto Alegre, RS, Brazil. (rott@fzb.rs.gov.br)

\begin{abstract}
The new genus Neodrassex is proposed to include two new species of Gnaphosidae from Brazil. Neodrassex aureus sp. nov. is described from Amazonas, Paraná and Rio Grande do Sul states, and N. iguatemi sp. nov. is described from Paraná state. Neodrassex gen. nov. is characterized by small size, pale coloration, large anterior median eyes surrounded by black pigmentation, absence of a dorsal abdominal scutum in males and by the cheliceral dentition with 2-3 teeth on the promargin and 2-4 on the retromargin. The new genus is tentatively placed at the Leptodrassex group.
\end{abstract}

KEYWORDS. Neotropical Region, Brazil, spiders, taxonomy.

RESUMO. Neodrassex, um gênero novo do grupo Leptodrassex (Araneae, Gnaphosidae) da América do Sul. O gênero novo Neodrassex é proposto para incluir duas espécies novas de Gnaphosidae do Brasil. Neodrassex aureus sp. nov. é descrita do Amazonas, Paraná e Rio Grande do Sul; N. iguatemi sp. nov. é descrita do Paraná. Neodrassex gen. nov. inclui aranhas pequenas de coloração pálida com olhos médios anteriores de maior tamanho circundados de pigmento preto, machos sem escudo dorsal no abdômen e quelícera com 2-3 dentes na promargem e 2-4 na retromargem. O gênero é tentativamente incluido no grupo Leptodrassex.

PALAVRAS-CHAVE. Região Neotropical, Brasil, aranhas, taxonomia.

The gnaphosid Leptodrassex group was proposed by Murphy (2007) to include the simultaneously proposed genus Leptodrassex Murphy, 2007. This genus currently includes four species from the Mediterranean, Canary Islands and Asia, all formerly placed in Leptodrassus Simon, 1878 (Murphy, 2007; Platnick, 2012).

According to MurPhy (2007), Leptodrassex species were separated from Leptodrassus primarily because of their unusual dentition, with 2-4 "discrete small" teeth on the promargin of the chelicerae and 2-3 teeth on the retromargin. Other diagnostic characters cited for Leptodrassex are: small size (2-4 $\mathrm{mm})$, pale coloration, lack of dorsal abdominal scutum in males, anterior median eyes surrounded with black pigment and larger than the other eyes when viewed from the front.

While revising the unidentified Gnaphosidae vials in the arachnological collection of the Museu de Ciências Naturais da Fundação Zoobotânica do Rio Grande do Sul, several specimens were found presenting similar somatic characteristics to Leptodrassex. By a closer examination I was able to identify two distinct female morphospecies and one male. The cheliceral tooth formula of the examined specimens, with 2-3 teeth on the promargin and 2-4 on the retromargin doesn't agree exactly with the Lexptodrassex genus dentition presented by Murphy (2007). The herein examined specimens also don't match any known Leptodrassex species in the shape of the external female genitalia (which presents a large, divided atrium) or male palp morphology (with small, hooked, slightly sclerotized and translucent median apophysis). Based on the provided evidence (tooth formula and the regular appearance of female genitalia) the new genus is proposed and tentatively placed in the Leptodrassex group sensu MURPHY (2007).

\section{MATERIAL AND METHODS}

The specimens examined are deposited in the arachnological collection of the Museu de Ciências Naturais, Fundação Zoobotânica do Rio Grande do Sul (MCN, E. H. Buckup and R. Ott), Porto Alegre, Brazil. The description format follows Отт et al. (2012) with inclusion of descriptions of male and female palp spination. Only leg articles with spines are indicated. All femoral dorsal spines are considered erect and bristle-like; all remaining article spines are considered surface bearing. The female epigynum was dissected and immersed in clove oil for clearing in order to facilitate the study and imaging of its structures.

Abbreviations: AME, anterior median eye; ALE, anterior lateral eye; PM, cheliceral promargin; PLE, posterior lateral eye; PME, posterior median eye; RM, cheliceral retromargin.

Incident light images were taken through a stereomicroscope with attached camera and processed with Helicon Focus multi-range program. Drawings were made using a stereomicroscope with attached camera lucida. Transmitted light images of cleared female epigyna were taken with a compound microscope using a digital camera and also processed with Helicon Focus. Electron scanning microscope (SEM) images were taken using a Jeol-JSM-5200 with attached SLR digital camera. All measurements are in millimeters. 


\section{Neodrassex gen. nov.}

(Figs 1-47)

Type-species. Neodrassex aureus sp. nov.

Etimology. Neodrassex is a contraction between Neotropical and Leptodrassex. Gender is masculine.

Diagnosis. Neodrassex resembles Leptodrassex in the small size, pale coloration, larger AME surrounded with black pigment, absence of a dorsal abdominal scutum in males, presence of lateral epigynal processes (Figs 39, 45; see also Kovblyuk \& Nadolny, 2010:194, figs 28-30) and posteriorly directed fertilization ducts in the internal female genitalia (Figs 1, 40, 46; see also Murphy, 2007:519-520); Neodrassex species can be distinguished from Leptodrassex by the cheliceral dentition with 2-3 teeth on the PM and 2-4 teeth on the RM (Figs 20-22, 47); males can be distinguished by the shape of the palp bulb with a flat, hooked, slightly sclerotized and translucent MA rising from a deep depression on the apical portion of the tegulum (Figs 5-7, 9-16); females can be identified by the shape of the external female genitalia, which present a large atrium with a narrow median septum (Figs 37, 39, 43, 45).

Note. The presence of a larger number of
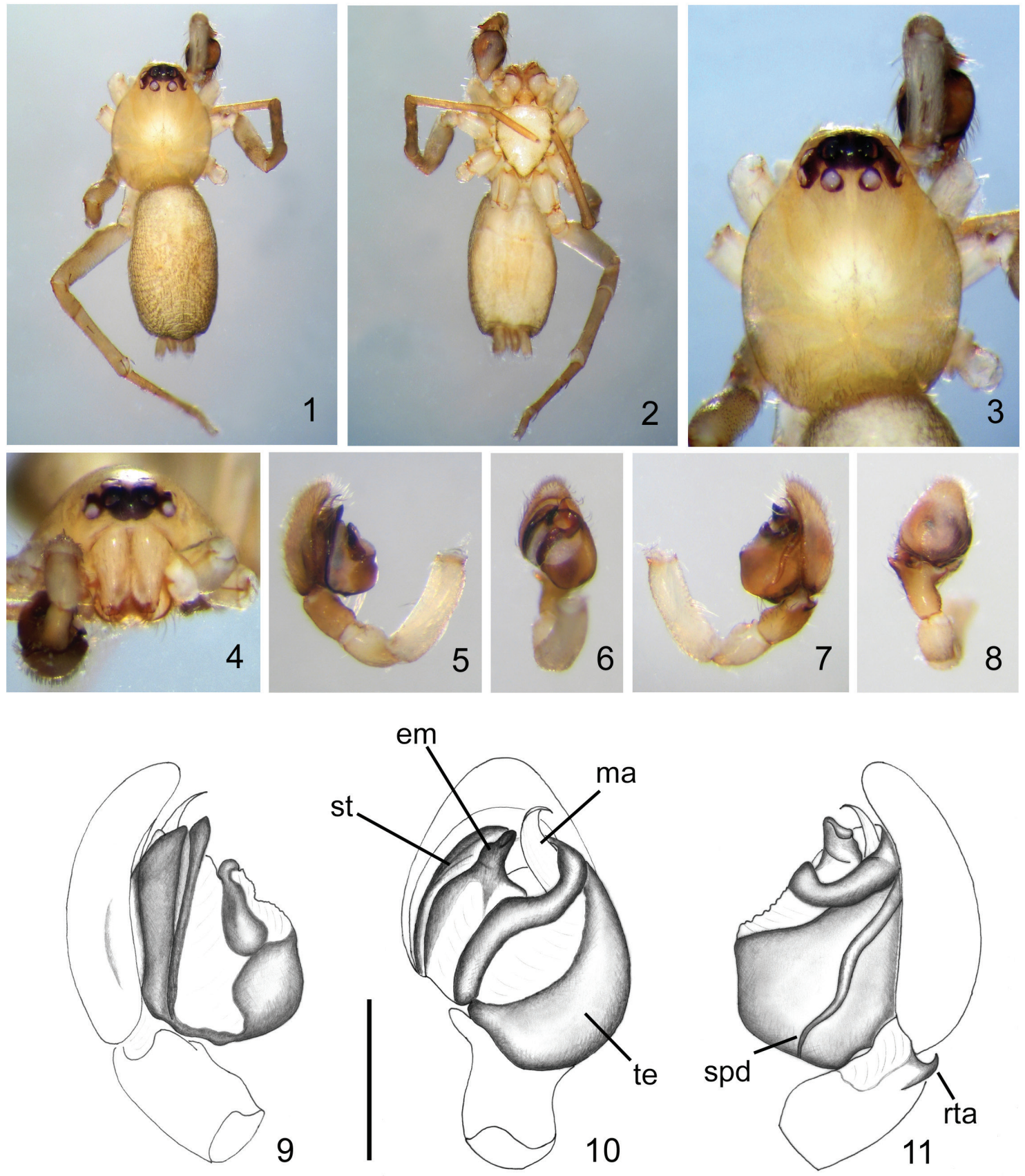

Figs 1-11. Neodrassex aureus sp. nov. (holotype $\widehat{\partial}$, MCN 43646): 1, dorsal; 2, ventral; carapace: 3, dorsal; 4, anterior; palp: 5, 9, prolateral; 6, 10 , ventral; 7, 11, retrolateral. Scale $=0.25 \mathrm{~mm}$ (em, embolus; ma, median apophysis; rta, retrolateral tibial apophysis; spd, spermatic duct; st, subtegulum; te, tegulum). 
independent teeth on the promargin of the chelicera seems to be the more common pattern in Gnaphosidae. The equal number of teeth on both margins and especially a larger number of teeth on the retromargin (as presented by Neodrassex gen. nov.) are unusual patterns, at least for neotropical gnaphosids.

Description. Carapace, sternum, endites, chelicerae yellowish, coxae yellowish, remaining leg articles yellowish to light brown. Abdomen, dorsal: pale yellow sometimes with olive-brown spotted areas near borders. Abdomen, ventral: yellowish. Total length males 2.59-2.68; females 2.89-4.28. Clypeus size about equal to AME diameter. Eyes: AME surrounded with back, largest. Legs: relatively long compared with body size, with relatively long, weak spines. Male palp: tibia with broad border at prolateral distal
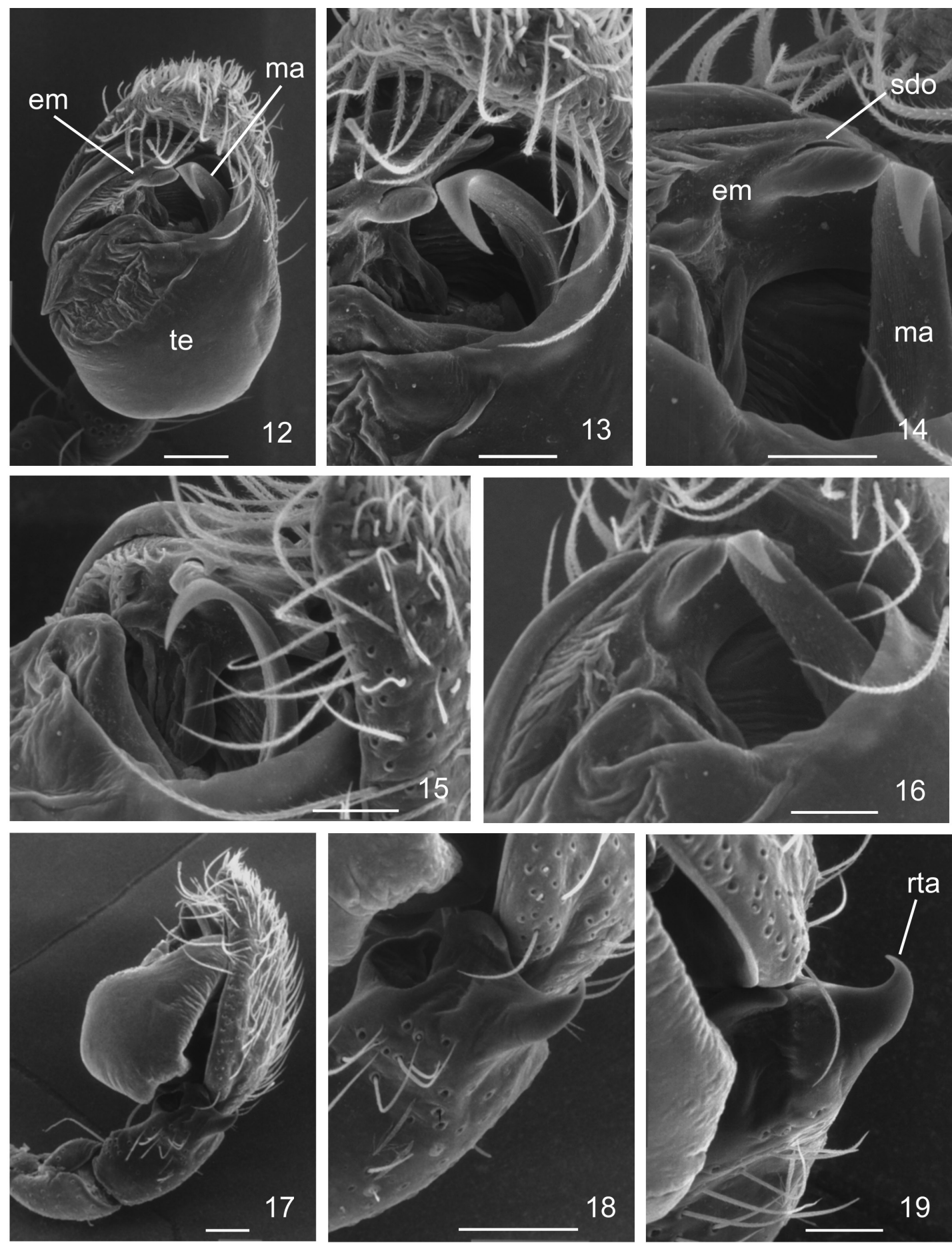

Figs 12-19. Neodrassex aureus sp. nov., male, Scanning Electron Microscope images. Palp: 12, ventral-apical, 17, retrolateral; median apophysis: 13, ventral-apical, 15, retrolateral, 16, ventral; 14, embolus, ventral; 18, tibia, retrolateral; 19, tibial apophysis, retrolateral. Scales: Fig. $12=500$ $\mu \mathrm{m}$; Figs 13-16, $19=50 \mu \mathrm{m}$; Figs 17-18 = $100 \mu \mathrm{m}$ (em, embolus; ma, median apophysis; sdo, spermatic duct opening; rta, retrolateral tibial apophysis). 

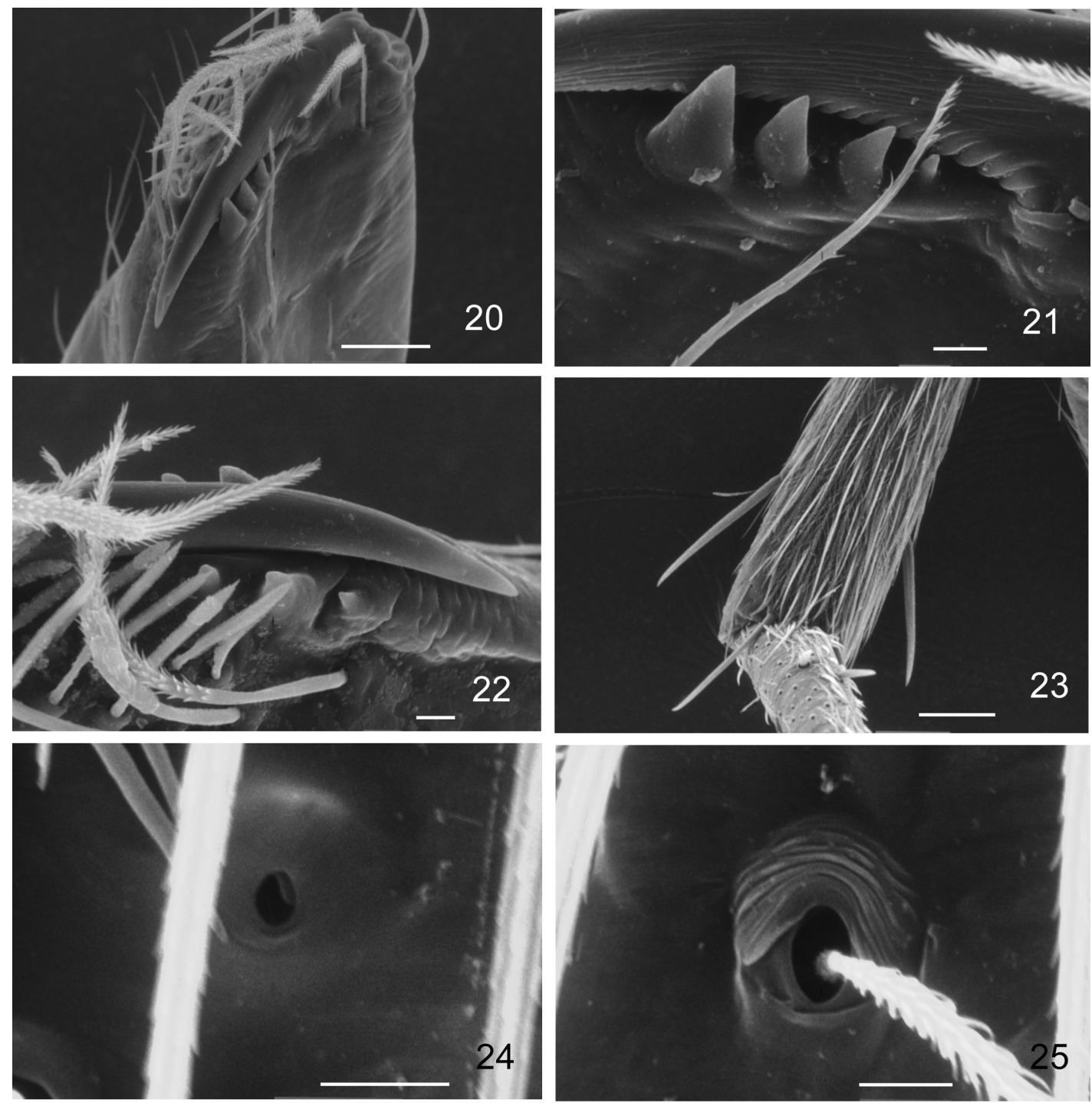

Figs 20-25. Neodrassex aureus sp. nov., male, Scanning Electron Microscope images. Chelicera: 20, mesal, 21, retromargin, 22, promargin; 23, distal tibia IV, ventral; leg I: 24, tarsal organ, 25, trichobothrium. Scales: Fig. $20=50 \mu \mathrm{m}$; Figs 21, $22=10 \mu \mathrm{m}$; Fig. $23=500 \mu \mathrm{m}$; Figs 24,25 $=5 \mu \mathrm{m}$.

end, small retrolateral apophysis (Figs 6-8, 10-11, 1719); bulb rounded, slightly longer than wide; tegulum sclerotized basally, soft distally with oblique sclerotized ridge surrounding median apophysis (Figs 5-11); median apophysis flat, translucent, hooked, originating on deep, rounded, distal tegular depression; embolus stout, distally darkened, originating on distal half of bulb (Figs 10-16). Epigynum with large semicircular atrium divided by narrow septum; openings at posterior portion of epigynum; lateral epigynal processes present; internal genitalia with relative small, oval to elongate spermathecae; relatively short, curved copulatory ducts; posteriorly directed fertilization ducts (Figs 37-40, 4346).

Distribution. Brazil (Amazonas, Paraná and Rio Grande do Sul).

Note. There are a large number of gnaphosoids which are introduced or have wide distributions ranges (Platnick, 2012). Due to the large distribution range of at least one of the herein described species, along with the proximity of some of the collection areas to highly impacted anthropic environments, there is for now a considerable doubt about the biogeographic origin of Neodrassex species. However other Neotropical species of spiders from other families (e.g. Linyphiidae) have the same distribution pattern and similar collection sites from Amazonas (Fazenda Esteio, Manaus) to state of Rio Grande do Sul (Everton N. L. Rodrigues, pers. comm.).

\section{Neodrassex aureus sp. nov.}

(Figs 1-40)

Type material. Holotype $\widehat{o}$ from Parque Copesul de Proteção Ambiental, Triunfo, Rio Grande do Sul, Brazil, 12.XI.2007, A. Barcellos \& L. Schmidt col. deposited in MCN 43646. Paratypes: 20 , , Parque Estadual do Turvo, Derrubadas, Rio Grande do Sul Brazil, 19-22.X.2004, R. Ott et al. col. (MCN 39784); 2 \%, São Francisco de Paula, Rio Grande do Sul, Brazil, 16.XII.1999, A. B. Bonaldo col. (MCN 32054). 
Etymology. The specific name is a latin adjective in honor of the golden wedding anniversary (1962-2012) of my father and my mother, Germano Rudolfo Ott and Elke Elisabeth Ott.

Diagnosis. Males and females of Neodrassex aureus sp. nov. can be recognized by the presence of three teeth on the PM and four on the RM. The species can be also recognized by the shape of the male palp (Figs 5-19) and by the shape of the female genitalia (Figs 35-40).

Description. Male (MCN 43646, holotype). Coloration (Figs 1-4): carapace, sternum yellowish with dark borders; endites, chelicerae yellowish, coxae yellowish, remaining leg articles light brown. Abdomen, dorsal: pale yellow with olive-brown spotted areas near borders. Abdomen, ventral: pale yellow with olive-brown spotted areas near borders. Total length 2.59. Carapace 1.21 long, 0,92 wide. Eye diameters and interdistances: AME 0.11, ALE 0.08, PME 0.06, PLE 0.08, AME-AME 0.08, AME-ALE 0.03, PME-PME 0.1, PME-PLE 0.06, ALE-PLE 0.02. Leg measurements: I - femur 1.12/ patella 0.49 / tibia $0.92 /$ metatarsus 0.79 / tarsus $0.43 /$ total 3.75; II - 1.12/ 0.46/ 0.95/ 0.82/ 0.53/ 3.88; III - 0.89/ $0.39 / 0.66 / 0.62 / 0.33 / 2.89$; IV $-1.83 / 0.49 / 0.99 / 1.12 /$ $0.26 / 4.69$. Leg spination: femur, IV r0-0-1; tibiae, I-II v2-2-0, III v1-1-0, p1-1-1 III-IV r0-1-1, IV v0-1-2, p0-11; metatarsi, I-II v0-1-0, III, p0-1-2, r0-0-1 III-IV v0-2-1, IV d0-1-1, p-r0-1-1. Palp spination: femur, d1-1-0. Leg IV with unsclerotized, collapsed distal portion (Fig. 29). Legs covered with many long setae, branched plumose hairs (Fig. 23); hairs sometimes lost, given very glabrous aspect to specimens. Tarsal organ elevated, with smooth
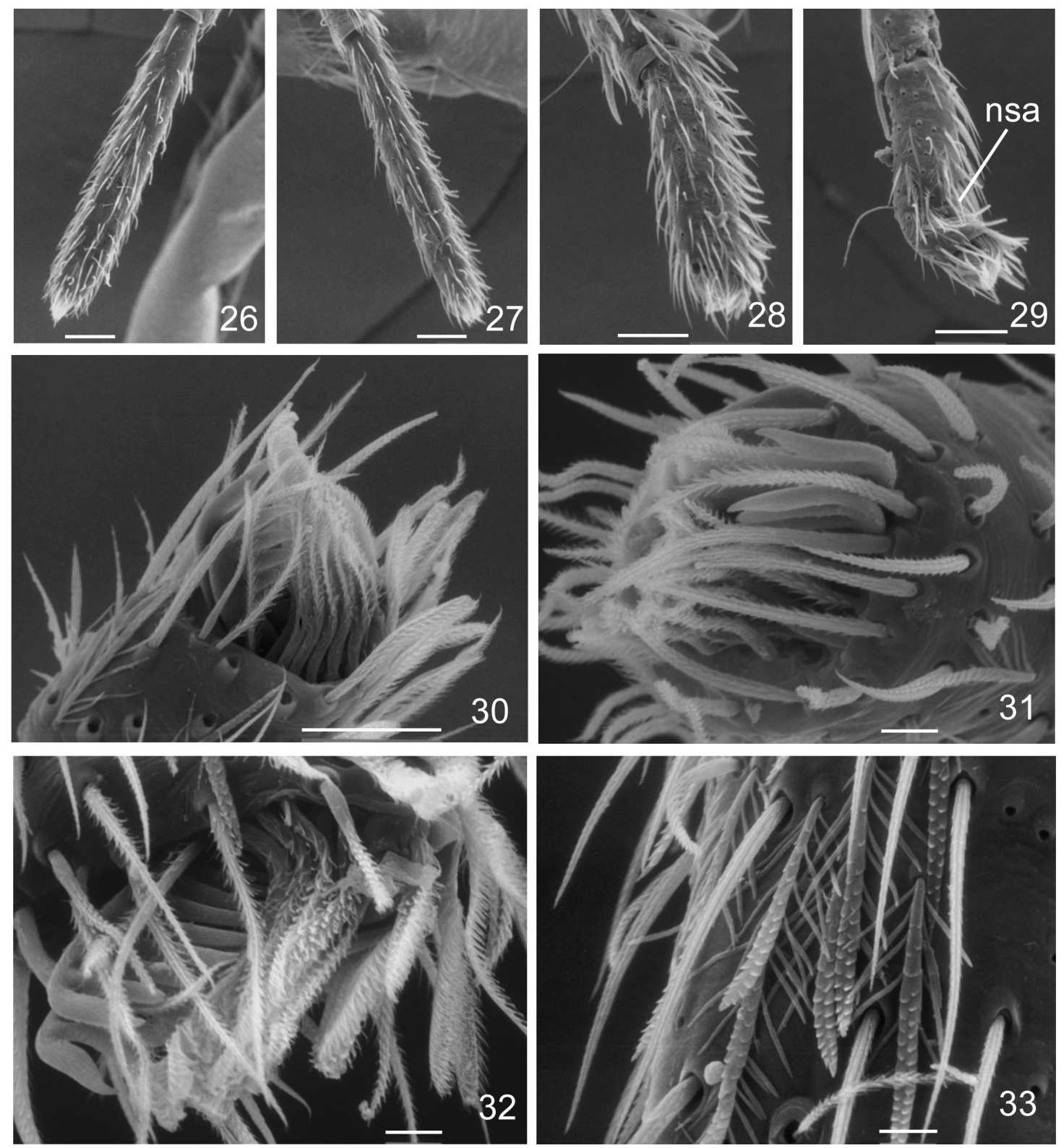

Figs 26-33. Neodrassex aureus sp. nov., male, Scanning Electron Microscope images. Tarsi: 26, leg I, 27, leg II, 28, leg III, 29, leg IV; claws: 30, leg IV, lateral; 31, leg II, lateroapical, 32, leg III, lateroapical; 33, plumose hairs, tarsi I. Scales: Figs 26-29=100 $\mu \mathrm{m}$; Fig. $30=50 \mu \mathrm{m}$; Figs $31-33=10 \mu \mathrm{m}$ (nsa, not sclerotized area). 
border, oval apperture (Fig. 24); thrichobothrial base elongated oval with wrinkled proximal border (Fig. 25). Leg plumose hairs usually with five pairs of branches, scale-like processes (Fig. 40). Palp: tibia with broad prolateral distal border; small, stout, hooked retrolateral tibial apophysis (Figs 6-8, 17-19); bulb rounded, longer than wide; tegulum sclerotized basally, soft distally with obliquous sclerotized ridge surronding MA which is flat, translucid, hooked, originating on rounded distal tegular depression; embolus stout, distally darkned, originating on distal half of bulb (Figs 5-16).

Female (MCN 32054, paratype). Coloration (Figs 34,35): Carapace, sternum, endites, chelicerae yellowish, coxae to tibia yellowish, metatarsi, tarsi slightly darker. Abdomen, dorsal, ventral: pale yellow. Total length 3.76. Carapace 1.41 long, 1.02 wide. Eye diameters and interdistances: AME 0.11, ALE 0.1, PME, 0.08, PLE 0.1; AME-AME 0.1, AME-ALE 0.03, PME-PME 0.11,
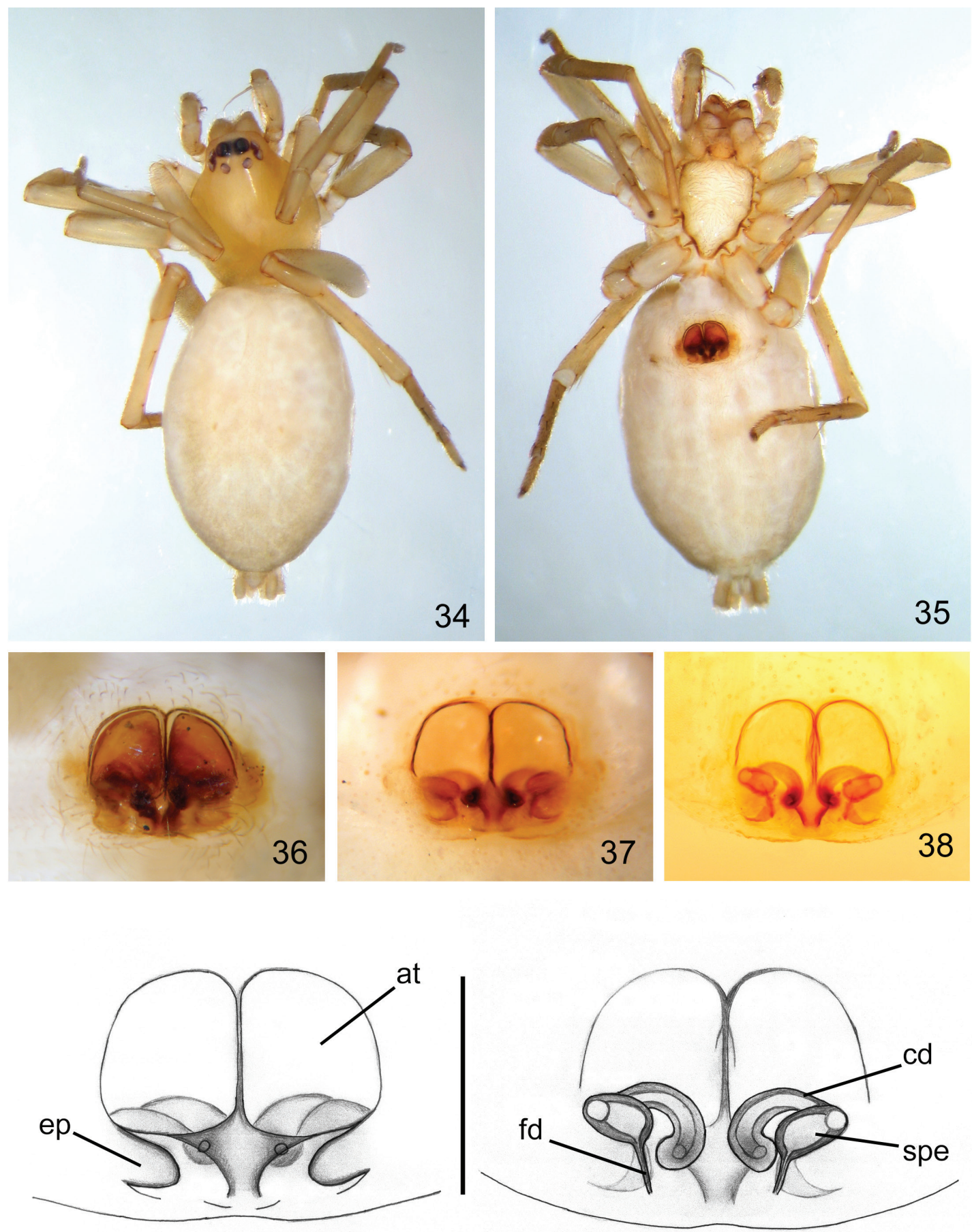

39

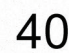

Figs 34-40. Neodrassex aureus sp. nov. (paratype + , MCN 32054): 34, dorsal; 35, ventral; epigynum: 36, with secretion, ventral, not dissected; 37 , without secretion, ventral, not dissected; 38,40 , dorsal; 39, ventral. Scales $=0.25 \mathrm{~mm}$ (at, atrium; cd, copulatory ducts; ep, epyginal process; fd, fertilization ducts; spe, spermathecae). 
PME-PLE 0.06, ALE-PLE 0.02. Leg measurements: I - femur 1.18 / patella 0.53 / tibia 0.89 / metatarsus $0.72 /$ tarsus $0.53 /$ total $3.85 ; \mathrm{II}-1.18 / 0.39 / 0.66 / 0.76 / 0.56 /$ 3.55; III - 0.99/ 0.49/ 0.66/0.62/ 0.33/ 3.09; IV - 1.51/ $0.56 / 0.92 / 1.18 / 0.33 / 4.5$. Leg spination: tibiae, I-II v22-0, III, v1-1-0, III-IV p-r0-1-1, IV, v1-1-2; metatarsi, I, v0-2-1, II, v0-2-0, III, v0-2-1, III-IV, p0-1-2, r 0-0-1, IV, d0-1-1, v1-1-1. Palp spination: femur, d1-1-0; tibia, v1-
$0-0, \mathrm{p} 2-0-0$; tarsus v1-0-1, p2-0-1, r0-2-0. Epigynal plate almost as long as wide, with large semicircular atrium divided by narrow septum; copulatory openings on posterior portion of epigynum, smaller then copulatory ducts in width; lateral epigynal processes large (Fig. 39), larger then copulatory duct width; internal genitalia with relative small, oval, elongated spermathecae, relatively short, curved copulatory ducts; posteriorly directed
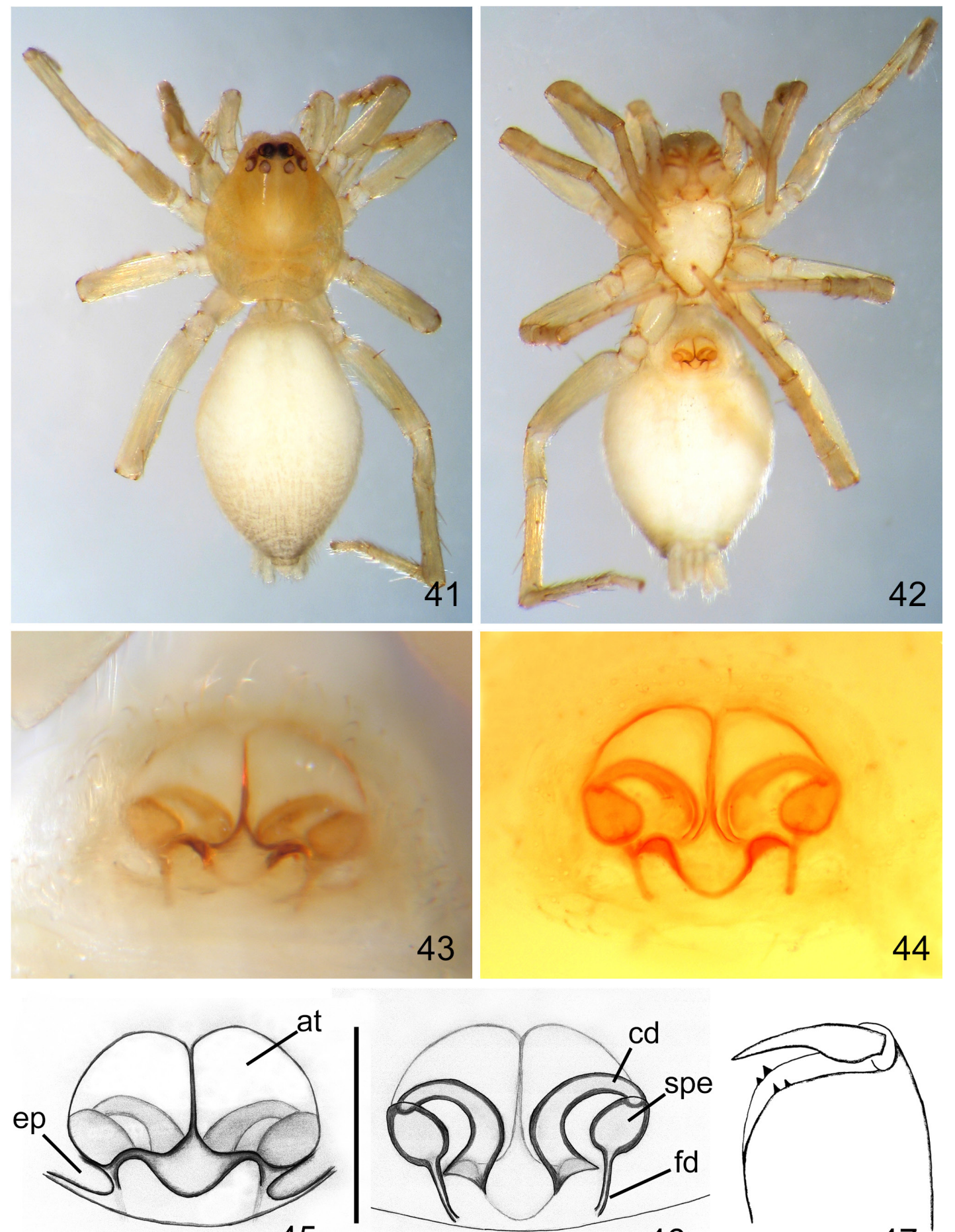

45
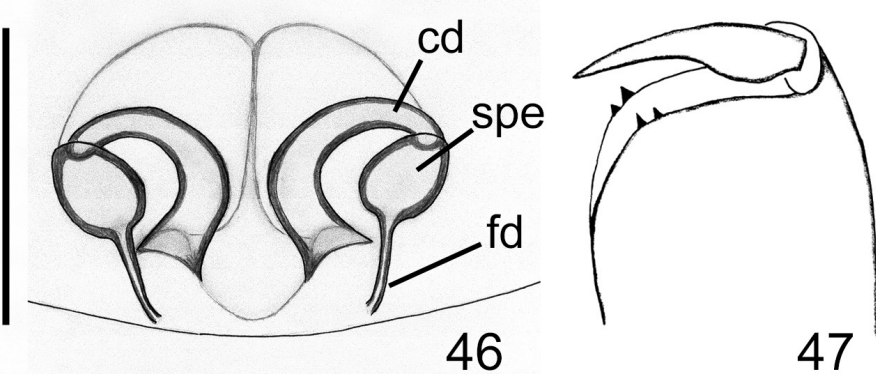

Figs 41-47. Neodrassex iguatemi sp. nov. (holotype 9 , MCN 12333): 41, dorsal; 42, ventral; epyginum: 43, ventral, not dissected, 44, 46, dor$\mathrm{sal}, 45$, ventral; 47, chelicerae, posterior view. Scale $=0.25 \mathrm{~mm}$ (at, atrium; cd, copulatory duct; ep, epyginal process; fd, fertilization duct; spe, spermathecae). 
fertilization ducts (Figs 37-40). Genital plate sometimes covered with heavy sclerotized secretion (Figs 35, 36). Variation. Total length: males 2.59-2.68, females 3.764.28 .

Other material examined. BRAZIL, Amazonas: Fazenda Esteio (30 km N Manaus), ô, 16.X.1985, B. Klein col. (MCN 21574); Paraná: Curitiba, 3 9, 02.XI.1987, A. D. Brescovit col. (MCN 17305); Rio Grande do Sul: Triunfo (Parque Copesul de Proteção Ambiental, actually Estação Ambiental Braskem), +, 06.I.2005, R. Ott et al. col. (MCN 38256); Estação Ambiental Braskem, +, 04.XII.2009, M. R. M. Poeta col. (MCN 46922).

Distribution. Brazil (Amazonas, Paraná and Rio Grande do Sul).

\section{Neodrassex iguatemi sp. nov. (Figs 41-47)}

Type material. Holotype $q$ from Iguatemi, Paraná, Brazil, 29.XII.1980, A. M. Geahl col., deposited in MCN 12333.

Etymology. The noun in apposition refers to the type locality.

Diagnosis. Neodrassex iguatemi sp. nov. differs from $N$. aureus sp. nov. by the presence of two teeth on both the RM and PM of the chelicerae (Fig. 47), by the shorter epigynal plate (wider than long), and by the smaller lateral epigynal processes (Figs 43-46).

Description. Female. Carapace, sternum, endites, chelicerae yellowish, legs yellowish. Abdomen, dorsal, ventral: pale yellow. Total length 2.89. Carapace 1.11 long, 0.95 wide. Eye diameters and interdistances: AME 0.1, ALE 0.08, PME 0.06, PLE 0.08; AME-AME 0.06, AME-ALE 0.03, PME-PME 0.1, PME-PLE 0.05, ALEPLE 0.02. Leg measurements: I - femur 0.79/ patella
0.39 / tibia $0.59 /$ metatarsus $0.52 /$ tarsus $0.39 /$ total 2.68; II $-0.82 / 0.39 / 0.62 / 0.59 / 0.39 / 2.81$; III $-0.69 / 0.36 /$ $0.49 / 0.46 / 0.30 / 2.3$; IV $-1.08 / 0.46 / 0.79 / 0.85 / 0.30 /$ 3.48. Leg spination: femora, I-II, IV d1-0-0, III d0-10 , III-IV r0-0-1; tibiae, I-III v2-2-0, III-VI p-r0-1-1, IV v0-1-2; metatarsi, I v0-2-0, II v0-2-1, III v0-2-2, p1-10, III-IV r1-0-1, IV d-v1-0-2, p-r1-0-1. Palp spination: femur, d1-0-0; tibia, p2-0-0; tarsus, d0-1-0, v1-0-1, p2-0-1, r0-2-0. Epigynal plate wider than long, with large semicircular atrium divided by narrow septum; copulatory openings positioned on posterior portion of epigynum, as large as copulatory ducts in width; lateral epigynal processes smaller than copulatory duct width (Figs 45, 46); internal genitalia with relative small, oval spermathecae; copulatory ducts relatively short, curved, narrowing toward spermathecae; posteriorly directed fertilization ducts (Figs 43-46).

Male. Unknown.

Distribution. Known only from the type locality.

Acknowledgements. To anonymous reviewers for helpful comments on the manuscript.

\section{REFERENCES}

Kovblyuk, M. M. \& Nadolny, A. A. 2010. Cryptodrassus hungaricus and Leptodrassex memorialis from Crimea (Aranei: Gnaphosidae). Arthropoda Selecta 19:189-197.

Murphy, J. A. 2007. Gnaphosid genera of the world. St Neots, British Arachnological Society 1:I-XII, 1-92; 2:I-11, 93-605.

Otт, R.; Rodrigues, E. N. L. \& Brescovit, A. D. 2012. Seven new species of Latonigena (Araneae: Gnaphosidae) from South America. Iheringia, Série Zoologia 102(2):227-238.

PlatNick, N. I. 2012. The world spider catalog, version 12.5. New York, American Museum of Natural History. Available at: $<$ http://research.amnh.org/iz/spiders/catalog $>$. Accessed on: 10. VII.2012. 